The American Journal of Political Science Law and Criminology

(ISSN - 2693-0803)

VOLUME 04 ISSUE 01 Pages: 1-6

SJIF IMPACT FACTOR (2020: 5. 453) (2021: 5. 952)

OCLC -1176274523 METADATA IF -7.659

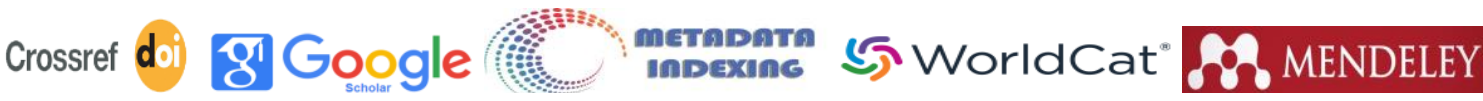

Research Article

\title{
ISSUES OF INTRODUCING DIGITAL TECHNOLOGIES INTO THE ACTIVITIES OF COURTS
}

\author{
Submission Date: December 15, 2021, Accepted Date: January 01, 2022, \\ Published Date: January 08, 2022 | \\ Crossref doi: https://doi.org/10.37547/tajpslc/Volume04lssue01-01 \\ Khudoynazarov Dadakhon Avaz \\ Lecturer at the Department Civil Procedure and Economic Procedure Law, Uzbekistan
}

Copyright: Original
content from this work may be used under the terms of the creative commons attributes 4.0 licence.

\section{ABSTRACT}

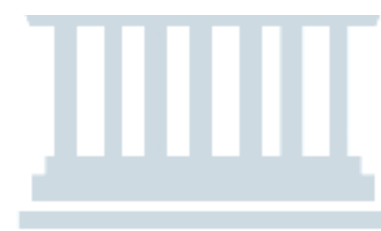

In the article discusses the work done on the implementation of modern digital technologies in courts, electronic document flow in courts during a pandemic, the activities of electronic sites, statistics on the electronicization of the judicial system, problems in practice, legislation, domestic and foreign experience, improvement of legislation.

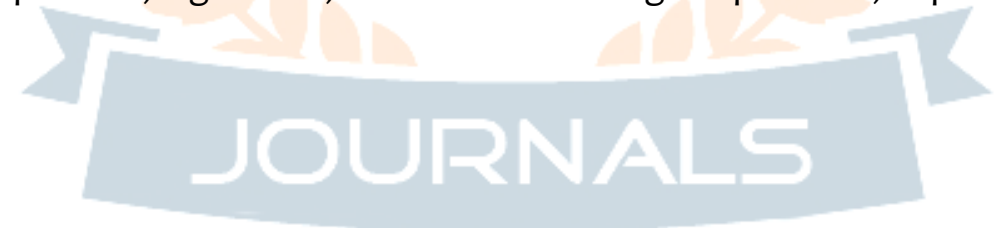

\section{KEYWORDS}

Courts, judges, electronic, information and communication, “E-SUD”, video conference, pandemic, statistic.

\section{INTRODUCTION}

Today, at a time when the Internet is developing rapidly around the world, users have the opportunity to provide information and data quickly and widely and use it effectively. Similarly, the process of informatization of the judicial system in our country is being carried out at a rapid pace. It is no exaggeration 
The American Journal of Political Science Law and Criminology (ISSN - 2693-0803)

VOLUME 04 ISSUE 01 Pages: 1-6

SJIF IMPACT FACTOR (2020: 5. 453) (2021: 5. 952)

OCLC - 1176274523 METADATA IF - 7.659

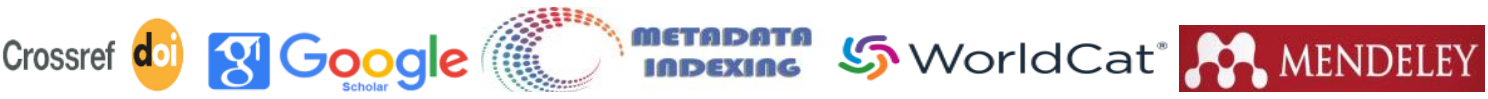

Resolution No. PP-4818 of September 3, 2020 "On measures to digitize the activities of the judiciary" The adoption of these decisions has led to many positive changes and achievements in matters related to the use and application of digital technologies in the activities of the courts.

The use of modern digital technologies in the courts in the context of a complex pandemic has led to the possibility of online dispute resolution.

Widespread introduction of modern digital technologies in the activities of courts - Internet reception, interactive map of courts of general jurisdiction of the Republic of Uzbekistan, resumes of vacancies for judges and court staff, active electronic communication with individuals and legal entities, courts, government and other organizations and courts and creates a number of conveniences based on the study of the experience of foreign countries.

First, to ensure openness, transparency and efficiency of the judiciary, to increase the quality of judicial proceedings and public awareness of justice, to eliminate red tape, bureaucracy and abuse by the judiciary.

Second, to avoid taking more time to make a final decision on the case before the court.

Third, to resolve disputes more quickly by the courts and to prevent an increase in the number of cases pending before the courts.

Fourth, expand the range of interactive services provided by courts to individuals and legal entities.

Fifth, online monitoring of each application process will be provided,

Sixth, free access to interactive services in courtrooms. 
The American Journal of Political Science Law and Criminology

(ISSN - 2693-0803)

VOLUME 04 ISSUE 01 Pages: 1-6

SJIF IMPACT FACTOR (2020: 5. 453) (2021: 5. 952)

OCLC - 1176274523 METADATA IF - 7.659

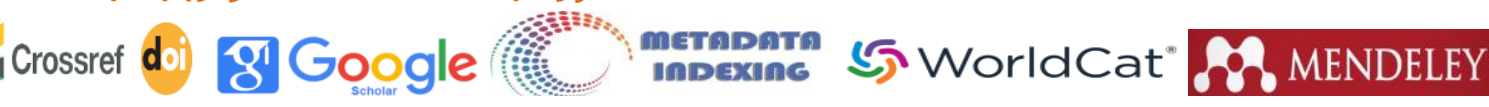

It is also planned to develop a mobile application that

Seventh, the parties will be able to obtain court decisions online.

Eighth, recording in court using audio recordings during the trial.

Ninth, the automatic distribution of cases among judges in the courts of first instance.

Tenth, to inform all participants of the court on a free basis about the time and place of court hearings via SMS.

Eleventh, to submit court decisions to the parties online, and at their request in paper form.

Twelfth, electronic submission and receipt of court cases to the state archives.

Thirteenth, the electronic exchange of information with ministries and agencies in the course of court proceedings.

Fourteenth, the submission of claims, applications and complaints to the courts only in electronic form by public authorities and administration, local public authorities, economic authorities, lawyers.

Fifteenth, online monitoring of the process of consideration of claims, applications and complaints by stakeholders.

Sixteenth, to ensure information security and secure circulation of electronic documents in the judicial system. 
The American Journal of Political Science Law and Criminology (ISSN - 2693-0803)

VOLUME 04 ISSUE 01 Pages: 1-6

SJIF IMPACT FACTOR (2020: 5. 453) (2021: 5. 952)

OCLC -1176274523 METADATA IF -7.659

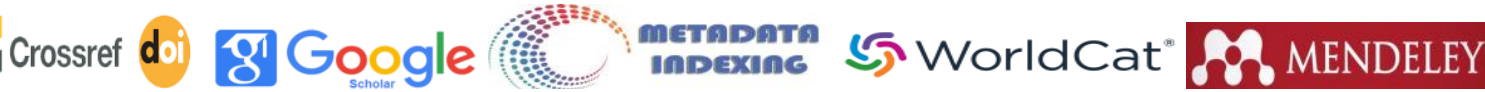

Publisher: The USA Journals

\begin{tabular}{|c|c|c|c|c|c|c|c|c|}
\hline \multicolumn{9}{|c|}{$\begin{array}{c}\text { Хуқуқ устуворлиги индексининг индикаторлари бўйича } \\
\text { Ўзбекистонга берилган баллар тахлили }\end{array}$} \\
\hline \multirow{2}{*}{\multicolumn{3}{|c|}{ ahuqu }} & \multicolumn{2}{|c|}{ Балл } & \multirow{2}{*}{$\begin{array}{c}\text { Ўзгариш } \\
\text { } \downarrow\end{array}$} & \multicolumn{2}{|c|}{ Ўрин } & \multirow{2}{*}{$\begin{array}{c}\check{У ̆}_{\text {згариш }} \\
\uparrow \downarrow\end{array}$} \\
\hline & & & 2020 & 2021 & & 2020 & $2021^{*}$ & \\
\hline \multicolumn{3}{|c|}{ Хуқуқ устуворлиги индекси } & 0.47 & 0,49 & $\uparrow 0,02$ & 92 & 78 & $\uparrow 14$ \\
\hline 1 & \multirow{8}{*}{$\begin{array}{l}0 \\
\frac{0}{\pi} \\
5 \\
0 \\
0 \\
\frac{0}{\pi} \\
\frac{5}{5} \\
\frac{0}{1} \\
\frac{1}{5}\end{array}$} & $\begin{array}{l}\text { Хукумат ваколатлари } \\
\text { чекланганлиги }\end{array}$ & 0.33 & 0,38 & $\uparrow 0,05$ & 120 & 110 & $\uparrow 10$ \\
\hline 2 & & $\begin{array}{l}\text { Коррупция мавжуд } \\
\text { эмаслиги }\end{array}$ & 0.40 & 0,46 & $\uparrow 0,06$ & 89 & 63 & $\uparrow 26$ \\
\hline 3 & & Хукумат очиқлиги & 0.33 & 0,37 & $\uparrow 0,04$ & 120 & 112 & $\uparrow 8$ \\
\hline 4 & & Фундаментал хуқуқлар & 0.41 & 0,44 & $\uparrow 0,03$ & 110 & 101 & $\uparrow 9$ \\
\hline 5 & & Тартиб ва хавфсизлик & 0.90 & 0,90 & - & 11 & 12 & $\downarrow 1$ \\
\hline 6 & & Қонунларга риоя этиш & 0.44 & 0,44 & - & 96 & 95 & $\uparrow 1$ \\
\hline 7 & & Фуқаролик одил судлов & 0.51 & 0,50 & $\downarrow 0,01$ & 72 & 71 & $\uparrow 1$ \\
\hline 8 & & Жиноий одил судлов & 0.44 & 0,45 & $\uparrow 0,01$ & 66 & 60 & $\uparrow 6$ \\
\hline
\end{tabular}

Electronicization of our courts is also based on foreign experience.

So, according to the UK experience today, in economic and civil courts, the amount of claims does not exceed ten thousand pounds, less important cases are resolved through the online court platform. (The Code of Economic Procedure of the Republic of Uzbekistan also provides for a simplified procedure, but does not provide for the resolution of cases through an online court platform). The main advantage of the online court platform is that the parties will be able to participate in court hearings from anywhere and resolve disputes in a short time.

There are also law firms in foreign countries (UK, USA) that resolve disputes independently, and disputes are resolved in a very quick and convenient way.

https://www.ebay.com - engages in online trading and resolves trade-related disputes. It is initially indicated that it will be resolved by mutual agreement. If the dispute is not resolved, the company employee will resolve the dispute fully online within ten days.

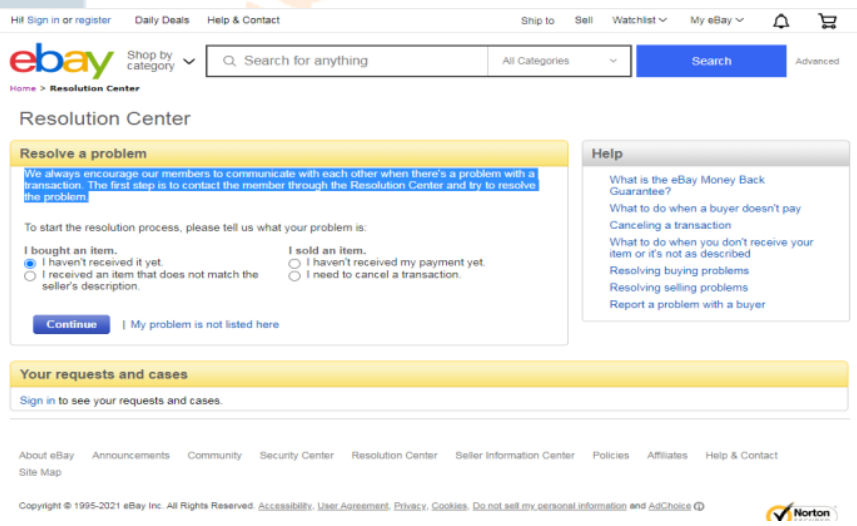

https://www.modria.com - resolve civil and economic disputes quickly and cheaply wherever they wish. Since then, the need for courts in dispute resolution has been declining, with courts being used as a final step in dispute resolution. 
The American Journal of Political Science Law and Criminology (ISSN - 2693-0803)

VOLUME 04 ISSUE 01 Pages: 1-6

SJIF IMPACT FACTOR (2020: 5. 453) (2021: 5. 952)

OCLC - 1176274523 METADATA IF - 7.659

\section{Crossref dol g' Google}

Third, to improve the existing procedural order and

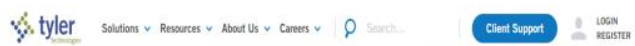

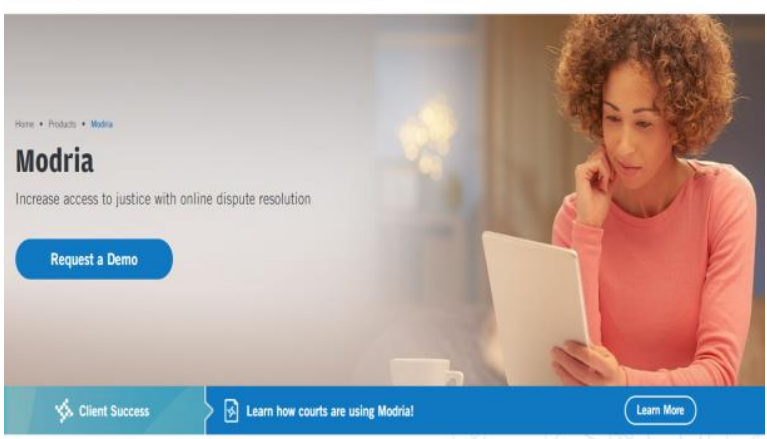

Deliver Fast and Fair Online Dispute Resolution

Also, the introduction of digital technologies in the judicial system is a cornerstone in the administration of justice, increasing the transparency and efficiency of the system. For example, HM Courts \& Tribunals Service Digital Case System in the UK has reduced the amount of paper used since 2015 by 500 tonnes and reduced the time required to file a claim from 15 working days to 10 minutes. These statistics show that by 2023 , more than 2 million cases a year will be spent outside the real courtroom, bringing the total to 244 million. Pound savings are planned. Eighty-four percent of document exchange in Singapore courts is done through electronic technology. Video conferencing is widely used in the courts of leading countries such as Hungary, USA, UK, Netherlands, Belgium, Italy, Ireland, Australia, UAE, Singapore, Canada.

Based on the above, we should make the following suggestions and recommendations to improve the electronicization of the judiciary.

First, the introduction of a single "Electronic Court" system, which collects all the sites and electronic information on the activities of the courts.

Second, a drastic reduction in paper costs by creating an electronic bank of cases in the courts. non-human monitoring of violations of deadlines in the court proceedings.

Fourth, the launch of the Online Judicial Platform based on the Electronic Judicial System and its implementation in three stages.

a) Online assessment - helps to determine the type, basis and subject of the dispute and to explain the rights and obligations of the applicants.

b) Online consultant - the dispute is resolved without the participation of a judge. It also acts as a mediator at the same time.

c) An online judge will resolve the dispute by mutual agreement of the parties, failing which a judge will be involved.

In conclusion, the new changes in the judiciary strengthen its role in protecting the rights and legitimate interests of citizens. Modernization of the judicial system through the effective introduction of digital technologies in the judiciary, as well as reliable protection of the rights and freedoms of citizens, entrepreneurs and legal entities, remote access to the courts, resolving issues without visiting the courthouse, effective videoconferencing to strengthen the confidence of our people in the judicial system through the automatic distribution of cases among judges, the publication of the final conclusions of the court on the Internet and the sending of executive documents in electronic form using information technology, to turn the court into a real "fortress of justice".

\section{REFERENCES}

\section{Normative and legal documents}

1. Resolution of the President of the Republic of Uzbekistan dated August 30, 2017 “On measures to 
The American Journal of Political Science Law and Criminology

(ISSN - 2693-0803)

VOLUME 04 ISSUE 01 Pages: 1-6

SJIF IMPACT FACTOR (2020: 5. 453) (2021: 5. 952)

OCLC -1176274523 METADATA IF -7.659

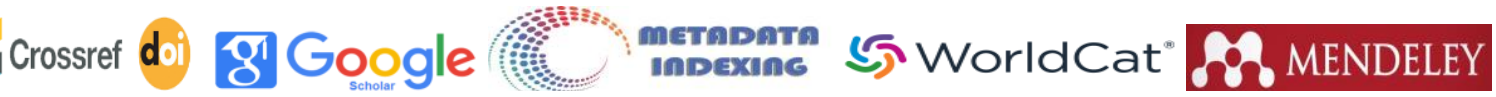

further improve the introduction of modern information and communication technologies in the courts".

\section{Additional literature}

2. B.Ochilov. Head of the Department for the Introduction of Information and Communication Technologies and Information Security of the Supreme Court.

3. Law on the Supreme Council of Judges of the Republic of Uzbekistan. http://hudud24.uz/sudlarfaoliyatida-akhborot-tehnologiyalariochi\%D2\%9Blik-va-shaffoflikka-hizmat-\%D2\%9Bildi/

4. http://hudud24.uz/uzbekiston-hukuk-ustuvorligiindeksida-14-pogona-yukurildi.

5. I.Saidov, Assistant Judge of Bukhara Interdistrict Economic Court and Master of Brunel University London.

6. Shavkatovich P. O. THE PROCEDURAL ASPECTS OF ELECTRONIC EVIDENCE IN CIVIL LITIGATION: EXPERIENCE OF UZBEKISTAN//PalArch's Journal of Archaeology of Egypt/Egyptology. - 2020. - T. 17. №. 7. - C. 9192-9199.

7. Худайбергенов, Б. Б. (2016). Вопросы правового регулирования судебной санации как процедуры банкротства в Республике Узбекистан. Приложение $\mathrm{K}$ журналу Предпринимательское право, (3), 34-36.

\section{Internet resources}

8. https://strategy.uz/index.php?news=1115

9. lex.uz

10. sud.uz 